Dementia

and Geriatric

Cognitive Disorders
Dement Geriatr Cogn Disord 2006;21:175-181

DOI: $\underline{10.1159 / 000090733}$
Accepted: October 18, 2005

Published online: January 9, 2006

\title{
An Estimate of the Worldwide Prevalence and Direct Costs of Dementia in 2003
}

\author{
A. Wimo L. Jonsson B. Winblad \\ Division of Geriatric Epidemiology, Neurotec, Karolinska Institutet, Stockholm, Sweden
}

\section{Key Words}

Worldwide direct costs $\cdot$ Worldwide prevalence .

Cost of illness

\begin{abstract}
Dementia disorders are today considered to be a major driver of costs in health care and social systems and worrying estimates of future dementia prevalence have been presented. It is of great interest for policy makers to have an estimate of dementia disorders' contribution to global social and health care costs, particularly in light of the demographic prognoses. The worldwide costs of dementia were estimated from prevalence figures for different regions, and cost-of-illness studies from key countries using a model based on the relationship between direct costs of care per demented and the gross domestic product per capita in each country. The worldwide direct costs for dementia in 2003 are estimated at 156 billion USD in the main scenario based on a worldwide prevalence of 27.7 million demented persons (sensitivity analysis: 129-159 billion USD). Ninety-two percent of the costs are found in the advanced economies with $38 \%$ of the prevalence. Although there are several sources of uncertainty, it is obvious that the worldwide costs are substantial and the expected increase in elderly people in the developing countries presents a great challenge.
\end{abstract}

Copyright @ 2006 S. Karger AG, Basel

\section{Introduction}

Dementia disorders are today considered to be a major driver of costs in health care and social systems of developed countries. The main reason is the 'greying population', and pessimistic estimates of future dementia prevalence and costs have been presented [1-3]. A new situation for the millennium is the 'greying' of the developing countries, which may present a scenario for dementia care and costs that is even more worrying. However, this view is affected by severe methodological problems. Even if there are controversies regarding how to perform costof-illness studies and cost-effectiveness research in the developed countries, we are indeed facing great methodological problems if we intend to include developing countries in the analyses. Methodological challenges from the worldwide perspective include, for example, accuracy of dementia prevalence estimates, different care systems, issues related to the costing of informal care and, last but not least, the incompleteness of data in many developing countries. Nevertheless, we regard it as important to try to estimate the worldwide costs of dementia, since it may be of great interest for policy makers to have a rough estimate of dementia disorders' contribution to global social and health care costs, particularly in light of the demographic statistics showing that the majority of demented persons live in developing countries. Since the prognoses also show that the greatest increase in the num-

\section{KARGER \\ Fax +4161306 1234 E-Mail karger@karger.ch} www.karger.com www.karger.com/dem
Dr. Anders Wimo

HC Harmånger

Backv 3

SE-820 75 Harmånger (Sweden)

Fax +46 652 71261, E-Mail Anders.Wimo@neurotec.ki.se 
ber of demented will occur in these countries [4], an estimate of the costs will have consequences for how these countries will organize and finance the care for demented persons.

\section{Materials and Methods}

Two basic sources for the calculations were used: epidemiological data regarding the prevalence of dementia in different parts of the world, and available sources regarding cost of illness of dementia. These sources are combined in a model which estimates the worldwide costs of dementia. The cost-of-illness model used in this paper refers to the methods in a paper by Andlin-Sobocki et al. [5] although the present model is somewhat simplified due to the availability of data. The basic assumption is that there is a relationship between the direct costs and resources for dementia care and the gross domestic product (GDP) per capita [6].

\section{Epidemiology: The Worldwide Occurrence of Dementia}

In a previous paper [4], we presented an estimate of the worldwide occurrence of dementia. This estimate was based on the worldwide demographic statistics from the United Nations (UN) and the best available data on age-class-specific dementia prevalence [7]. In the present paper, the prevalence figures are updated to 2003 .

The UN presents demographic statistics (5-year age classes) and forecasts for countries, regions and the world [8]. In the forecast we used, the 1997 version, there is a deviation of just $0.3 \%$ from the latest prognoses. It is also assumed that the age-specific dementia prevalence is similar worldwide. In the sensitivity analysis, different sources for age-specific dementia prevalence are tested $[9,10]$.

\section{Cost of Illness}

The cost of the illness due to a disease in question is equal to the value of what these resources would have produced if there had been no cases of the illness, i.e. opportunity costs. Two approaches can be used: an incidence approach or a prevalence approach [11]. If the aim is to illustrate the economic consequences of various interventions, the incidence approach is preferable. If the aim is to estimate the economic burden during e.g. a year, the prevalence approach is recommended, as in the present study.

The perspective of a cost of illness assessment informs the reader of whose viewpoint the costs are calculated from. The societal perspective includes all costs, irrespective of the payer, and is recommended by most published guidelines for economic evaluations [12]. In the case of dementia, this means that informal care is assigned a cost. However, due to the great methodological problems in calculating the costs of informal care from a worldwide perspective, this paper focuses on direct costs.

Costs are calculated as the product of the quantities of resources consumed (q) and a price vector (p). As definitions of care resources vary between countries and published cost-of-illness studies rarely disaggregate quantities and prices, this analysis was based on the total cost estimates reported in previous research.
The Worldwide Perspective

The worldwide perspective presents several methodological difficulties. Country-specific cost-of-illness studies are based on demographics of the elderly, dementia occurrence figures and an estimate or knowledge of how demented persons are distributed in the care organization and their use of resources. To these basic figures, a theory of costing must be added. Such a detailed approach is not possible when a worldwide perspective is applied. Even if there are several country-specific cost-of-illness studies published, such studies do not represent all the different regions of the world. The range of costs illustrates not only true differences in the costs of dementia, but also that the differences reflect methodological aspects, such as whether costs of informal care are included or not and how informal care is costed. Other methodological problems are incompleteness of demographic statistics of the elderly and of information on how demented persons are distributed in various kinds of care organizations of the elderly in different parts of the world. Since a great proportion of costs occur outside the formal medical system, such as home services, nursing home care, informal care, it is not sufficient to use medical register data.

Results are here presented as world continent figures but also according to International Monetary Fund/World Economic Outlook's (WEO) terminology as 'advanced economies' and 'other emerging market and developing countries' [13] as well as according to the UN terms 'more developed regions' (MDR) and 'less developed regions' (LDR) [8] and the World Bank's 4-level classification [14].

\section{The Economic Model}

Since many countries lack specific cost data on dementia, a method for imputation of such data needs to be used. Imputation is based on a selection of cost data concerning dementia from countries where such data are available. Different imputation algorithms based on international statistical data to reach the most appropriate estimates for countries with no original cost data are used. From macro-economic research it is well known that there is a strong correlation between expenditures on health care per capita and the GDP per capita [15, 16]. A similar relationship can be used to make an estimate of the worldwide costs of dementia, based on two approaches. The first (which is the base option) assumes that the expenditures per demented person as a proportion of GDP per capita for the countries and regions where imputation is necessary is similar to the proportion in the countries where dementia cost data are available. It is accordingly assumed that differences between countries in unit costs, e.g. costs of hospital care, are reflected in differences in the GDP per capita and year. Furthermore, it is also assumed that differences in GDP per capita also reflect differences in care resources (e.g. countries with a high GDP per capita and year have more costly caring resources, such as long-term care, than countries with low GDP per capita).

The second approach (in the sensitivity analysis) is based on the assumption that expenditures of health care per capita reflect dementia costs worldwide.

All costs are expressed as US dollars in 2003 (currency transformations by the use of Purchase Power Parities [17]) and for the time transformation of costs to the year of 2003 the Consumer Price Index for each source country was used [18].

The criteria for inclusion of cost-of-illness studies from the key countries was that transparent and established methods for cost-ofillness calculations were used. It should also be possible to identify 
Table 1. The worldwide population and worldwide dementia population

\begin{tabular}{lrrrr}
\hline Major areas/regions & $\begin{array}{c}\text { Population } \\
2003, \mathrm{n} \times 1,000\end{array}$ & $\begin{array}{r}\text { Proportion of } \\
\text { population, } \%\end{array}$ & $\begin{array}{l}\text { Demented } \\
2003\end{array}$ & $\begin{array}{l}\text { Proportion of } \\
\text { demented, \% }\end{array}$ \\
\hline Africa & $838,462.8$ & 13.4 & $1,354,033$ & 4.9 \\
Eastern & $264,659.6$ & 4.2 & 359,334 & 1.3 \\
Middle & $103,909.1$ & 1.7 & 164,034 & 0.6 \\
Northern & $183,217.7$ & 2.9 & 377,897 & 1.4 \\
Southern & $48,259.8$ & 0.8 & 87,299 & 0.3 \\
Western & $238,416.6$ & 3.8 & 365,469 & 1.3 \\
Latin America & $541,294.7$ & 8.6 & $1,867,134$ & 6.7 \\
Caribbean & $38,443.5$ & 0.6 & 188,767 & 0.7 \\
Central & $142,284.7$ & 2.3 & 426,847 & 1.5 \\
South & $360,566.4$ & 5.7 & $1,251,521$ & 4.5 \\
Northern America & $316,467.0$ & 5.0 & $3,282,080$ & 11.8 \\
Asia & $3,823,656.4$ & 60.9 & $13,209,989$ & 47.6 \\
Eastern & $1,518,013.8$ & 24.2 & $7,204,199$ & 26.0 \\
South Central & $1,565,087.1$ & 24.9 & $4,011,709$ & 14.5 \\
South Eastern & $540,117.4$ & 8.6 & $1,449,370$ & 5.2 \\
Western & $200,438.0$ & 3.2 & 544,712 & 2.0 \\
Europe & $727,749.1$ & 11.6 & $7,787,243$ & 28.1 \\
Eastern & $305,056.1$ & 4.9 & $2,501,209$ & 9.0 \\
Northern & $94,422.0$ & 1.5 & $1,216,518$ & 4.4 \\
Southern & $144,017.0$ & 2.3 & $1,756,113$ & 6.3 \\
Western & $184,254.0$ & 2.9 & $2,313,404$ & 8.3 \\
European Union & $451,081.9$ & & $5,504,683$ & \\
Oceania & $31,523.6$ & 0.5 & 230,078 & 0.8 \\
Australia and & $23,382.2$ & 0.4 & 215,726 & 0.8 \\
$\quad$ New Zealand & $8,141.4$ & 0.1 & 14,351 & 0.1 \\
Other & $6,279,153.6$ & 100 & $27,730,557$ & 100 \\
\hline World & & & & \\
\hline & & & & \\
\hline
\end{tabular}

included cost categories, and a minimum requirement was that at least direct costs were presented. Some recalculations were made in order to obtain comparable cost figures.

Fourteen eligible studies were used [2, 19-31]. All studies are from the WEO's category for advanced economies. Since the selected studies represented countries with a wide range in the number of demented persons, the average ratio between direct costs of dementia and GDP per person was weighted versus the size of the dementia population in the countries from which studies were selected. The average weighted ratio between direct costs per demented person and GDP per person, which is used in the base option, was $43.6 \%$ (unweighted $44.0 \%$, median $41.2 \%$ ). The estimated worldwide direct cost is the sum of the estimated direct costs of all countries worldwide. The model can be expressed as an equation (for e.g. country A):

direct $_{\operatorname{cost}}(\text { country A) }=\text { direct cost per demented } \text { dkey countries })_{(} \times$ $\left[\mathrm{GDP}_{(\text {country A) }} / \mathrm{GDP}_{(\text {key countries })}\right] \times$ prevalence $_{(\text {country A) }}$.

\section{Results}

\section{Direct Costs}

In 2003, the estimated number of demented persons worldwide was 27.7 million (tables 1, 2), of which $38 \%$ lived in the advanced economies (47\% in the MDR part of the world). By far the greatest dementia population lives in China (5.2 million). The worldwide direct costs of dementia in 2003 were estimated to be 156.2 billion USD (tables 3, 4). In contrast to how the prevalence was distributed, $92 \%$ of the costs occur in the advanced economies/high-income countries (93\% in the MDR). The highest single country direct cost was in the USA, 48.6 billion USD, followed by Japan with 24.7 billion USD, while in the EU-25 region it was 60.5 billion USD. In China, the costs were estimated at 2.5 billion USD.

\section{Sensitivity Analysis}

The sensitivity analysis of the direct costs (table 5) showed a variation between 129 and 159 billion USD, 
Table 2. The worldwide population and worldwide dementia population in different economic areas

\begin{tabular}{|c|c|c|c|c|}
\hline Major areas/regions & $\begin{array}{l}\text { Population } \\
2003, \mathrm{n} \times 1,000\end{array}$ & $\begin{array}{l}\text { Proportion of } \\
\text { population, } \%\end{array}$ & $\begin{array}{l}\text { Demented } \\
2003\end{array}$ & $\begin{array}{l}\text { Proportion of } \\
\text { demented, \% }\end{array}$ \\
\hline $\begin{array}{l}\text { World } \\
\text { IMF/WEO classification }\end{array}$ & $6,279,153.6$ & 100 & $27,730,557$ & 100 \\
\hline Advanced economies & $921,770.2$ & 15 & $10,540,885$ & 38 \\
\hline $\begin{array}{l}\text { Other emerging market and developing } \\
\text { countries } \\
\text { UN classification }\end{array}$ & $5,357,383.4$ & 85 & $17,189,672$ & 62 \\
\hline $\begin{array}{l}\text { MDR } \\
\text { LDR }\end{array}$ & $\begin{array}{l}1,194,840.0 \\
5,084,313.6\end{array}$ & $\begin{array}{l}19 \\
81\end{array}$ & $\begin{array}{l}12,969,903 \\
14,760,654\end{array}$ & $\begin{array}{l}47 \\
53\end{array}$ \\
\hline World Bank classification & & & & \\
\hline Low income & $2,313,445.9$ & 37 & $5,202,278$ & 19 \\
\hline Lower middle income & $2,694,142.8$ & 43 & $10,371,024$ & 37 \\
\hline Upper middle income & $335,048.4$ & 5 & $1,542,461$ & 6 \\
\hline High Income & $936,516.4$ & 15 & $10,614,793$ & 38 \\
\hline OECD countries & $1,140,823.4$ & & $11,494,933$ & \\
\hline
\end{tabular}

IMF = International Monetary Fund; Advanced economies = China Hong Kong SAR, Japan, Republic of Korea, Singapore, Cyprus, Israel, Denmark, Finland, Iceland, Ireland, Norway, Sweden, UK, Greece, Italy, Portugal, Spain, Austria, Belgium, France, Germany, Luxembourg, The Netherlands, Switzerland, Canada, USA, Australia, New Zealand; LDR = Africa, Latin America and the Caribbean, Asia (excluding Japan), Melanesia, Micronesia and Polynesia; MDR = North America, Japan, Europe, Australia, New Zealand.

where the variation of prevalence resulted in the lowest cost. The alternative, based on expenditures on health, gave almost the same result as with the base option, which is not surprising since GDP per capita and expenditures on health are highly correlated. However, particularly between North America (mainly the USA, 63.7 billion USD in this option) and Europe there was a shift, depending on the high expenditures on health in the USA.

\section{Discussion}

It is important to stress the fact that the prevalence and cost figures presented in this paper must be seen as estimates rather than exact calculations of costs. To transform and compare cost results between different countries is difficult, as there are many ways to organize and finance care. Most sources also only cover some parts of the world, mainly the advanced economies. Another great problem is the incompleteness of data, both regarding demographics, care organization and costs. The use of macro-economic data, such as our GDP-based model, is a way to avoid these drawbacks.

The estimated number of demented individuals is also crucial for the estimation of the economic burden. Our prevalence figure, 27.7 million, which is an update of a previous calculation [4], is higher than figures presented in one WHO source (about 10 million [32] or 18 million), while it is lower than in another WHO publication (about 34 million) [33].

The key question in this paper is whether the combination of cost-of-illness data from the key studies and macro-economic data are applicable to other parts of the world. The figures from Europe can be compared with the figures presented in the paper by Andlin-Sobocki et al. [5] where a much more comprehensive battery of sources could be used. Our cost per demented is about $91 \%$ of the cost in their paper for the corresponding countries. However, it is hard to say whether it is appropriate to assume that the relationship between GDP data and social and health care resources is also valid from a worldwide perspective, particularly since the key studies are all from advanced economies. The knowledge about formal and informal care for demented persons in the developing countries is limited [34]. Even if it is logical to assume that in low-income countries the number of institutional resources is indeed low (or they are not existing), one can question the assumption that, for instance, an increasing GDP per capita correlates in a rather linear way to more (and costly) institutional care. The assumption that unit costs of dementia care correlate with GDP can also be questioned, although it is difficult from a worldwide per- 
Table 3. The estimated worldwide direct costs of dementia in 2003

\begin{tabular}{|c|c|c|c|c|}
\hline \multirow[t]{2}{*}{ Major areas/regions } & \multirow{2}{*}{$\begin{array}{l}\text { Direct costs, } \\
\text { billions US }\end{array}$} & \multirow[t]{2}{*}{ Percent } & \multicolumn{2}{|l|}{ Costs, USD } \\
\hline & & & $\begin{array}{l}\text { per demented } \\
\text { person }\end{array}$ & $\begin{array}{l}\text { per person } \\
0+\end{array}$ \\
\hline Africa & 0.53 & 0.3 & 393 & 0.6 \\
\hline Eastern & 0.06 & 0.0 & 163 & 0.2 \\
\hline Middle & 0.04 & 0.0 & 225 & 0.4 \\
\hline Northern & 0.25 & 0.2 & 650 & 1.3 \\
\hline Southern & 0.12 & 0.1 & 1,402 & 2.5 \\
\hline Western & 0.07 & 0.0 & 189 & 0.3 \\
\hline Latin America & 3.00 & 1.9 & 1,604 & 5.5 \\
\hline Caribbean & 0.47 & 0.3 & 2,505 & 12.3 \\
\hline Central & 0.98 & 0.6 & 2,298 & 6.9 \\
\hline South & 1.54 & 1.0 & 1,232 & 4.3 \\
\hline Northern America & 52.62 & 33.7 & 16,032 & 166.3 \\
\hline Asia & 31.96 & 20.5 & 2,419 & 8.4 \\
\hline Eastern & 28.87 & 18.5 & 4,007 & 19.0 \\
\hline South Central & 1.11 & 0.7 & 276 & 0.7 \\
\hline South Eastern & 0.88 & 0.6 & 610 & 1.6 \\
\hline Western & 1.10 & 0.7 & 2,019 & 5.5 \\
\hline Europe & 65.78 & 42.1 & 8,447 & 90.4 \\
\hline Eastern & 3.60 & 2.3 & 1,439 & 11.8 \\
\hline Northern & 16.38 & 10.5 & 13,462 & 173.4 \\
\hline Southern & 15.65 & 10.0 & 8,912 & 108.7 \\
\hline Western & 30.15 & 19.3 & 13,035 & 163.7 \\
\hline European Union & 60.47 & & 10,985 & 134.0 \\
\hline Oceania & 2.30 & 1.5 & 10,071 & 73.5 \\
\hline \multicolumn{5}{|l|}{ Australia and } \\
\hline New Zealand & 2.30 & 1.5 & 10,671 & 98.5 \\
\hline Other & 0.00 & 0.0 & 1,058 & 1.9 \\
\hline World & 156.20 & 100 & 5,633 & 24.9 \\
\hline
\end{tabular}

$0+=$ total population spective to confirm or reject it. An indirect support for this assumption may be the well-known correlation between expenditures on health care and GDP (even if most of the direct costs of dementia care can be regarded as non-medical). Nevertheless, we think that the estimates, with all these drawbacks, represent a rather valid estimate of the worldwide direct costs of dementia.

The dichotomous way of dividing the countries in the world (as 'advanced economies' vs. the 'other emerging market and developing countries' or MDR vs. LDR) is rather rough since there are, indeed, differences between countries in these categories, and many countries are in a transition toward a better economic situation. The World Bank classification offers somewhat more detailed information and can also catch the transitions in a better way.

The 'greying' of populations not only in the advanced economies, but also in the developing countries with an expected increase in the prevalence of dementia [4], will put a stress on the care systems in all countries. However, whether it is good or bad to build up a formal care infrastructure in the developing countries similar to that in the advanced economies (e.g. institutions, home medical care, day care) is hard to say, and the assumption that an economic transition with changing family patterns poses a threat to the elderly has been questioned [35]. On the other hand, in many advanced economies there is a trend of deinstitutionalization, often combined with an economic crisis in the public health and social systems, leading to other kinds of problems. Since dementia disorders are costly and also constitute a great part of the total costs in the welfare system, dementia disorders should be the focus for not only specific care planning on all levels in the society, but also for extensive cost-effectiveness research. 
Table 4. The estimated worldwide direct costs of dementia in different economic areas in 2003

\begin{tabular}{|c|c|c|c|c|}
\hline \multirow[t]{2}{*}{ Major areas/regions } & \multirow{2}{*}{$\begin{array}{l}\text { Direct costs, } \\
\text { billions USD }\end{array}$} & \multirow[t]{2}{*}{ Percent } & \multicolumn{2}{|l|}{ Costs, USD } \\
\hline & & & $\begin{array}{l}\text { per demented } \\
\text { person }\end{array}$ & $\begin{array}{l}\text { per person } \\
0+\end{array}$ \\
\hline World & 156.20 & 100 & 5,633 & 24.9 \\
\hline \multicolumn{5}{|l|}{ IMF/WEO classification } \\
\hline Advanced economies & 143.53 & 92 & 13,617 & 155.7 \\
\hline \multicolumn{5}{|l|}{ Other emerging market and } \\
\hline developing countries & 12.67 & 8 & 737 & 2.4 \\
\hline \multicolumn{5}{|l|}{ UN classification } \\
\hline MDR & 145.44 & 93 & 11,214 & 121.7 \\
\hline LDR & 10.76 & 7 & 729 & 2.1 \\
\hline \multicolumn{5}{|l|}{ World Bank classification } \\
\hline Low income & 1.1 & 1 & 216 & 0.5 \\
\hline Lower middle income & 7.3 & 5 & 705 & 3 \\
\hline Upper middle income & 3.7 & 2 & 2,411 & 11 \\
\hline High income & 144.0 & 92 & 13,570 & 154 \\
\hline OECD countries & 145.14 & 93 & 13,589 & 136.9 \\
\hline
\end{tabular}

0+ = total population; IMF = International Monetary Fund.
Table 5. Sensitivity analysis of the direct costs

\begin{tabular}{lrrrrr}
\hline & $\begin{array}{l}\text { Base } \\
\text { option }\end{array}$ & \multicolumn{1}{l}{$\begin{array}{l}\text { Prevalence } \\
{[10]}\end{array}$} & \multicolumn{1}{l}{$\begin{array}{l}\text { Prevalence } \\
\text { [9] }\end{array}$} & $\begin{array}{l}\text { GDP-based } \\
\text { (outliers excluded) }\end{array}$ & $\begin{array}{l}\text { Health } \\
\text { expenditures }\end{array}$ \\
\hline Africa & 0.53 & 0.55 & 0.43 & 0.51 & 0.70 \\
Latin America & 3.00 & 3.00 & 2.46 & 2.87 & 4.76 \\
Northern America & 52.62 & 51.41 & 43.40 & 50.49 & 67.79 \\
Asia & 31.96 & 31.84 & 26.44 & 30.67 & 25.76 \\
Europe & 65.78 & 64.78 & 54.68 & 63.12 & 57.30 \\
Oceania & 2.32 & 2.29 & 1.92 & 2.22 & 2.30 \\
\hline World & 156.20 & 153.87 & 129.33 & 149.90 & 158.62 \\
\hline
\end{tabular}

It is not easy to compare worldwide cost-of-illness studies, due to methodological issues (different methods for cost calculations, lack of data from many parts of the world, different care systems etc). The worldwide direct costs of diabetes, another long-lasting chronic disorder, has been estimated at 44.4 billion USD (in 1997) [36], giving a hint of the magnitude of the direct costs of dementia.

In conclusion, due to several sources of uncertainty, the range of cost estimates is relatively wide. The research database is small, particularly in the developing countries, and there is a great need for extensive research in a broad way. It is also necessary to perform cost studies from countries with different ways of financing and organizing care. Incomplete demographic statistics, different ways of financing and organizing dementia care, available resources and the relative importance of informal care are examples of factors that contribute to between-country variability and uncertainty in estimates. Nevertheless, it is obvious that the worldwide costs are substantial and the expected increase in elderly people in the developing countries presents a great challenge for social and health care systems.

\section{Acknowledgements}

The authors thank Prof. Laura Fratiglioni, Zarina Nahar Kabir, $\mathrm{PhD}$, and Katie Palmer, PhD, Stockholm Gerontology Research Center, for providing valuable comments. This study was supported by grants from the Swedish Research Council, Swedish Brain Power, the Old Servant's Foundation, SADF (in Swedish: Stiftelsen för Alzheimer och demensforskning, in English: Foundation for Alzheimer and Dementia Research) in collection, analysis of data and preparation of the manuscript. 


\section{References}

1 Schneider EL, Guralnik JM: The aging of America. Impact on health care costs. JAMA 1990;263:2335-2340.

$\checkmark 2$ Rice DP, Fox PJ, Max W, Webber PA, Lindeman DA, Hauck WW, et al: The economic burden of Alzheimer's disease care. Health Aff (Millwood) 1993;12:164-176.

3 Jonsson B, Jonsson L, Wimo A: Cost of dementia; in May M, Sartorius N (eds): Dementia. WPA Series Evidence and Experience in Psychiatry. London, Wiley \& Sons, 2000, pp 335363.

$\checkmark 4$ Wimo A, Winblad B, Aguero Torres H, von Strauss E: The magnitude of dementia occurrence in the world. Alzheimer Dis Assoc Disord 2003; 17:63-67.

$\checkmark 5$ Andlin-Sobocki P, Jonsson B, Wittchen HU, Olesen $\mathrm{J}$ : Cost of disorders of the brain in Europe. Eur J Neurol 2005;12(suppl 1):1-27.

6 Jacobzone S, Cambois E, Chaplain E, Robine $\mathrm{J}$ : Long term care services to older people, a perspective on future trends: the impact of an improved health of older persons. Report No AWP 4.2. Paris, OECD, 1998.

7 Fratiglioni L, Rocca WA: Epidemiology of dementia; in Boller F, Cappa SF (eds): Handbook of Neuropsychology, ed 2. Amsterdam, Elsevier, 2001, pp 193-215.

8 UN: World population prospects: The 1998 revision. World population 1950-2050. New York, United Nations, 1998.

9 Lobo A, Launer LJ, Fratiglioni L, Andersen K, Di Carlo A, Breteler MM, et al: Prevalence of dementia and major subtypes in Europe: a collaborative study of population-based cohorts. Neurologic Diseases in the Elderly Research Group. Neurology 2000;54(suppl 5):S4-S9.

$\checkmark 10$ Hofman A, Rocca WA, Brayne C, Breteler MM, Clarke M, Cooper B, et al: The prevalence of dementia in Europe: a collaborative study of 1980-1990 findings. Eurodem Prevalence Research Group. Int J Epidemiol 1991; 20:736-748.

11 Rice DP, Hodgson TA, Kopstein AN: The economic costs of illness: a replication and update. Health Financing Rev 1985;7:61-80.
12 Siegel JE, Torrance GW, Russell LB, Luce BR, Weinstein MC, Gold MR: Guidelines for pharmacoeconomic studies. Recommendations from the panel on cost effectiveness in health and medicine. Panel on cost Effectiveness in Health and Medicine. Pharmacoeconomics 1997;11:159-168.

13 World Economic Outlook: International Monetary Fund.http://www.imf.org/external/pubs/ $\mathrm{ft} / \mathrm{weo} / 2004 / 02 /$ data/index.htm.

14 World bank classification of economies, 2005. http://www.wordlbank.org/data/countryclass/ classgroups.htm.

15 Håkansson S: Different ways of organizing and financing health care; in Wimo A, Jönsson B, Karlsson G, Winblad B (eds): Health Economics of Dementia. London, Wiley \& Sons, 1998, pp 67-97.

16 Gerdtham UG, Lothgren M: On stationarity and cointegration of international health expenditure and GDP. J Health Econ 2000;19: 461-475.

17 International Monetary Fund: World Economic Outlook Database, 2004. http://www.imf. org/external/pubs/ft/weo/2004/02/data/index. htm\#countryinfo.

18 International Labour Organization: Laborsta Internet, 2004. http://laborsta.ilo.org/.

19 Ernst RL, Hay JW: The US economic and social costs of Alzheimer's disease revisited. Am J Public Health 1994;84:1261-1264.

20 Manton KG, Corder LS, Clark R: Estimates and projections of dementia-related service expenditures; in Suzman R, Singer B, Manton $\mathrm{KG}$ (eds): Forecasting the Health of the Oldest Old. New York, Springer, 1993, pp 207-238.

21 Ostbye T, Crosse E: Net economic costs of dementia in Canada. CMAJ 1994;151:14571464.

22 Hux MJ, O’Brien BJ, Iskedjian M, Goeree R, Gagnon M, Gauthier S: Relation between severity of Alzheimer's disease and costs of caring. CMAJ 1998;159:457-465.

23 McNamee P, Bond J, Buck D: Costs of dementia in England and Wales in the 21st century. Br J Psychiatry 2001;179:261-266.

-24 Smith KA, Shah A: The prevalence and costs of psychiatric disorders and learning disabilities. Br J Psychiatry 1995;166:9-18.
25 Holmes J, Pugner K, Phillips R, Dempsey G, Cayton H: Managing Alzheimer's disease: the cost of care per patient. Br J Health Care Management 1998;4:332-337.

26 Wimo A, Karlsson G, Sandman PO, Corder L, Winblad B: Cost of illness due to dementia in Sweden. Int J Geriatr Psychiatry 1997; 12:857861 .

27 Schulenberg J, Schulenberg I: Cost of treatment and cost of care for Alzheimer's disease in Germany; in Wimo A, Jonsson B, Karlsson G, Winblad B (eds): The Health Economics of Dementia. London, Wiley \& Sons, 1998, pp 217-230.

28 Kronborg Andersen C, Sogaard J, Hansen E, Kragh-Sorensen A, Hastrup L, Andersen J, et al: The cost of dementia in Denmark: the Odense Study. Dement Geriatr Cogn Disord 1999; 10:295-304.

29 Cavallo MC, Fattore G: The economic and social burden of Alzheimer disease on families in the Lombardy region of Italy. Alzheimer Dis Assoc Disord 1997;11:184-190.

30 Koopmanschap MA, Polder JJ, Meerding WJ, Bonneux L, van der Maas PJ: Costs of dementia in the Netherlands; in Wimo A, Jonsson B, Karlsson G, Winblad B (eds): The Health Economics of Dementia. London, Wiley \& Sons, 1998, pp 207-216.

31 O'Shea E, O'Reilly S: The economic and social cost of dementia in Ireland. Int J Geriatr Psychiatry 2000;15:208-218.

32 WHO: World Health report, 2004. www.who. int/whr/2004/annex/topic/annex3.xls.

33 Mathers C, Stein C, Ma Fat D, Rao C, Inoue M, Tomijima N, et al: Global burden of disease 2000. Version 2: methods and results. Global Programme on Evidence for Health Policy Discussion Paper No 50. Geneva, WHO, 2002.

34 Prince M: Care arrangements for people with dementia in developing countries. Int J Geriatr Psychiatry 2004; 19:170-177.

>35 Kabir ZN, Szebehely M, Tishelman C: Support in old age in the changing society of Bangladesh. Ageing Soc 2002;22:615-636.

36 Logminiene Z, Norkus A, Valius L: Direct and indirect diabetes costs in the world. Medicina (Kaunas) 2004;40:16-26. 